\title{
KOMUNIKASI PARTISIPATIF DALAM KONTEKS KEWIRAUSAHAAN SOSIAL PADA PROGRAM PERTANIAN PADI ORGANIK DI PANDEGLANG
}

\author{
Participatory Communication in The Context of Social \\ Entrepreneurship at The Organic Rice Agricultural Program in \\ Pandeglang) \\ Irpan Ripa'i Sutowo ${ }^{1}$, Pudji Muljono ${ }^{2}$, Musa Hubeis ${ }^{3}$ \\ ${ }^{1}$ Pusat Pendidikan dan Pelatihan Sumber Daya Manusia LPPM-IPB \\ ${ }^{2}$ Departemen Sains Komunikasi dan Pengembangan Masyarakat, FEMA-IPB \\ ${ }^{3}$ Departemen Manajemen, Fakultas Ekonomi dan Manajemen IPB \\ e-mail: irfanabdussalam@gmail.com
}

\begin{abstract}
Farmers welfare needs extra attention from agricultural development stakeholders. SRI's organic rice farming program implemented by the Harapan Dhuafa (Harfa) humanitarian agency in Parigi Village, Saketi Sub-district, Pandeglang District, Banten Province has scored social change agents. The steps taken by Harfa in running the program is through participatory communication approach in the process of adoption of organic rice farming innovation SRI method. The purpose of this study was to identify the characteristics of beneficiary individuals and to analyze the relationship of individual beneficiary characteristics, the intensity of participatory communication, the perception of program benefits and the level of social entrepreneurship, so that participatory communication in the context of social entrepreneurship can be well described in the organic rice farming program SRI. Research results show participative communication in the development of organic rice farming SRI method has a positive impact for the development of social entrepreneurship in Parigi Village. Through intensive participatory communication, the farmers actively engage in dialogue, arguing to reflect the results of the training/field schools in their respective fields. The emergence of individual beneficiary character in organic rice farming in increasing income and also awareness in improving environmental quality and health by producing and consuming organic rice. Based on the analysis using chi square correlation showed that there is no real relationship between the characteristics of individual beneficiaries with the intensity of participatory communication, the perception of program benefits and the level of social entrepreneurship. That is, the characteristics of individual beneficiaries is not a benchmark in an effort to increase organic rice farming methods SRI. Factors that have major influence on the intensity of participatory communication, the perception of program benefits and the level of social entrepreneurship.
\end{abstract}

Keywords: farmers welfare, participatory communication, social entrepreneurship 


\begin{abstract}
ABSTRAK
Kesejahteraan petani membutuhkan perhatian ekstra dari pemangku kepentingan pembangunan pertanian. Program pertanian padi SRI organik yang dilaksanakan oleh Lembaga Kemanusiaan Harapan Dhuafa (Harfa) di Desa Parigi, Kecamatan Saketi, Kabupaten Pandeglang, Propinsi Banten telah mencetak agen perubahan sosial. Langkah yang ditempuh Harfa dalam menjalankan program ini adalah melalui pendekatan komunikasi partisipatif dalam proses adopsi inovasi pertanian padi organik metode SRI. Tujuan dari penelitian ini adalah untuk mengidentifikasi karakteristik individu penerima manfaat dan untuk menganalisis hubungan karakteristik individu penerima manfaat, intensitas komunikasi partisipatif, persepsi manfaat program dan tingkat kewiraswastaan sosial, sehingga komunikasi partisipatif dalam konteks kewirausahaan sosial dapat digambarkan dengan baik dalam program pertanian padi organik metode SRI. Hasil penelitian menunjukkan bahwa komunikasi partisipatif dalam pengembangan metode pertanian padi sawah organik memiliki dampak positif bagi pengembangan kewirausahaan sosial di Desa Parigi. Melalui komunikasi partisipatif yang intensif, petani secara aktif terlibat dalam dialog, berpendapat melalui pembelajaran yang sesuai, sehingga terefleksikan hasil pelatihan di lahannya masing-masing. Munculnya karakter individu penerima manfaat dalam pertanian padi organik metode SRI dalam meningkatkan pendapatan dan juga kesadaran dalam meningkatkan mutu dan kesehatan lingkungan dengan memproduksi dan mengkonsumsi beras organik. Berdasarkan analisis dengan menggunakan korelasi khi kuadrat menunjukkan bahwa tidak ada hubungan nyata antara karakteristik individual penerima manfaat dengan intensitas komunikasi partisipatif, persepsi manfaat program dan tingkat kewirausahaan sosial. Artinya, karakteristik penerima manfaat individu bukanlah patokan dalam upaya meningkatkan metode pertanian padi organik SRI. Faktor yang memiliki pengaruh besar terhadap intensitas komunikasi partisipatif, persepsi manfaat program dan tingkat kewirausahaan sosial.
\end{abstract}

Kata kunci: kesejahteraan petani, kewirausahaan, komunikasi partisipasi

\title{
PENDAHULUAN
}

Permasalahan sosial terutama banyak dihadapi di negara-negara berkembang, yaitu meliputi masalah kesenjangan ekonomi, kesehatan, pendidikan, lingkungan, budaya, dan politik, sehingga kunci utama pemecahan masalah tersebut yaitu pembangunan untuk mencapai kesejahteraan sosial. Kesejahteraan sosial adalah kondisi terpenuhinya kebutuhan material, spiritual, dan sosial warga negara agar dapat hidup layak dan mampu mengembangkan diri, sehingga dapat melaksanakan fungsi sosialnya (Kemensos, 2009). Indonesia memiliki banyak permasalahan sosial, yang merupakan tanggung jawab bersama. Dibutuhkan proses komunikasi antar pemangku kepentingan (stakeholder) dalam pembangunan untuk menumbuhkan kesadaran, kemauan, dan kemampuan menggerakan serta mengembangkan partisipasi masyarakat. Proses tersebut ditunjang dengan penggunaan teknologi ataupun inovasi tepat guna. Mardikanto (2010) menyebutkan bahwa komunikasi pembangunan partisipatif ini muncul sebagai paradigma baru dalam proses komunikasi horizontal dalam penyampaian informasi, ide dan pendapat yang terus berlanjut dengan adanya dialog, sehingga terjadinya pertukaran informasi, ide dan pendapat hingga mencapai suatu kesepakatan bersama. 
Indonesia merupakan negara dimana penduduknya sebagian besar bermata pencaharian petani. Petani merupakan tulang punggung utama dalam pemenuhan kebutuhan pangan negara, oleh karena itu perhatian atas kesejahteraan petani sangatlah penting. Seperti yang dihadapi petani di Kabupaten Pandeglang, Provinsi Banten yang merupakan salah satu daerah pemekaran yang dulu termasuk dalam wilayah Provinsi Jawa Barat. Produktivitas padi di Kabupaten Pandeglang pada tahun 2014, yaitu 4.87 ton/ha yang merupakan nilai produktivitas padi terendah di Provinsi Banten. Hal ini tidak sebanding dengan potensi lahan persawahan Kabupaten Pandeglang yang terbesar di Provinsi Banten, yaitu 54.768 ha pada tahun 2014. Faktor utama penyebab terjadinya ketidakberdayaan petani dalam meningkatkan produktivitas padi yaitu kemiskinan. Tercatat pada tahun 2013 bahwa 17.87 persen penduduk di Kabupaten Pandeglang masuk dalam kategori miskin yang merupakan peringkat kedua terburuk setelah Kabupaten Tangerang (BPS 2015).

Salah satu stakeholder pembangunan yang fokus dalam menangani permasalahan sosial di Kabupaten Pandeglang adalah lembaga sosial kemanusiaan Harapan Dhuafa (Harfa) cabang Pandeglang. Aktivitas Harfa meliputi pengumpulan dana dan bantuan masyarakat, pembangunan masyarakat melalui pemberdayaan ekonomi, pendidikan, kesehatan, lingkungan, dan sosial. Harfa memiliki banyak program pembangunan yang bersinggungan langsung dengan masyarakat akar rumput, sehingga memerlukan pendekatan komunikasi partisipatif agar tercapainya kemandirian dan keberlanjutan manfaat kepada penerima manfaatnya. Salah satu program jangka panjang yang dilakukan oleh Harfa adalah program pengembangan pertanian padi organik metode system of rice intensification (SRI). Program tersebut memiliki tujuan utama untuk meningkatkan kesejahteraan petani melalui peningkatan produktivitas padi dan secara jangka panjang dapat meningkatkan mutu lingkungan, serta kesehatan masyarakat. Pada hakikatnya pertanian padi organik metode SRI lebih menguntungkan dibanding anorganik sekaligus berwawasan lingkungan seiring peningkatan kesadaran masyarakat akan bahayanya makanan non organik (Sugarda et al., 2008; Mayrowani, 2012). Melalui program tersebut pula, diharapkan dapat membentuk karakter petani mandiri yang berwawasan lingkungan. Hal ini merupakan salah satu benih terciptanya kewirausahaan sosial. Kewirausahaan sosial merupakan sebuah gerakan dengan misi sosial, yang diusahakan dengan upaya-upaya menemukan peluang dan mengolahnya dengan inovasi dan proses belajar yang tiada henti serta kesiapan untuk bertindak tanpa dukungan sumber daya yang memadai (Wibowo \& Nulhaqim 2015).

Tujuan penelitian secara umum : (1) untuk mengidentifikasi karakteristik individu penerima manfaat, (2) untuk menganalisis hubungan antara karakteristik individu penerima manfaat dengan persepsi kemanfaatan program, (3) untuk menganalisis hubungan antara intensitas komunikasi partisipatif dengan persepsi kemanfaatan program, (4) untuk menganalisis hubungan antara persepsi kemanfaatan program dengan tingkat kewirausahaan sosial pada progam pertanian padi organik metode SRI. 


\section{METODE PENELITIAN}

Metode penelitian disusun dengan menggunakan metode penelitian kombinasi (mixed methods) yang merupakan pendekatan penelitian campuran bentuk kualitatif dan kuantitatif yang melibatkan asumsi-asumsi filosofi, aplikasi pendekatan-pendekatan kualitatif dan kuantitatif serta campuran (mixing) kedua pendekatan tersebut dalam satu penelitian (Cresswell 2010). Lokasi penelitian dipilih secara purposif yaitu di Desa Parigi, Kecamatan Saketi, Kabupaten Pandeglang, Provinsi Banten. Penelitian ini dilaksanakan pada bulan Februari hingga Maret 2017. Populasi dalam penelitian ini merupakan individu penerima manfaat (IPM) program pertanian padi organik metode SRI yang dilaksanakan oleh Harfa. Pengambilan sampel dilakukan secara sensus, yaitu seluruh IPM yang berjumlah 56 orang. Analisis statistik menggunakan statistik deskriptif, korelasi khi kuadrat dan rank Spearman. Pengolahan data menggunakan Microsoft Excel 2007 dan SPSS 21.0

\section{HASIL DAN PEMBAHASAN}

\section{Karakteristik Penerima Manfaat}

Karakteristik individu penerima manfaat (IPM) program pertanian padi organik metode SRI terdiri dari rataan umur yang berkategori dewasa (53 persen) hingga tua (43 persen), sedangkan yang berusia muda hanya empat persen. Muchtar (2016), menjelaskan tentang peubah umur berpengaruh sangat nyata dan berkontribusi positif terhadap proses penerapan komunikasi partisipatif dan petani yang berada pada kategori dewasa antara 30-49 tahun merupakan kategori umur yang masih produktif. Responden penerima manfaat memiliki tingkat pendidikan formal sebagian besar rendah (SD) 70 persen dan sedang (SMP-SMA) 30 persen. Tingkat pendidikan berpengaruh terhadap program pertanian padi organik metode SRI di Desa Parigi. Terutama pada aktivitas kepercayaan diri responden dalam penyampaian pendapat. Jenis kelamin IPM mayoritas perempuan (66 persen), sedangkan laki-laki (19 persen). Penerima manfaat program berjenis kelamin perempuan dan laki-laki aktif dan antusias dalam menjalankan pelatihan di kelas maupun praktik di lapangan. Peran utama usahatani tetap di pegang oleh laki-laki, seperti pengolahan lahan, permodalan, dan penjualan, sedangkan peran utama perempuan kebanyakan pada aktivitas tandur, penyiangan, dan panen. Rataan pengalaman IPM bertani berkategori baru (45 persen) dan sedang (52 persen), sedangkan yang berkategori lama hanya dua persen. Penerima manfaat program dengan pengalaman bertani tersebut tentu akan membandingkan inovasi baru yang dapat lebih cermat, namun dalam penelitian ini diperoleh pengalaman bertani yang lama menjadikan petani lebih sadar akan pentingnya pertanian padi organik seperti yang telah dijalankan orang tua dulu, sehingga menimbulkan antusiasme tinggi dalam pertukaran informasi dan pengalaman dalam kegiatan pelatihan yang dilaksanakan oleh Harfa. Hal ini sesuai dengan hasil penelitian Machmuddin (2016) yang menjelaskan bahwa pengalaman berusahatani berbanding lurus dengan efisiensi usahatani, diduga karena semakin lama petani membudidayakan padi, maka pengetahuan dan pengalaman tentang teknik membudidayakan tanaman padi semakin baik. Rataan tingkat pendapatan IPM 
berkategori sedang (45 persen) dan sedang (53 persen), sedangkan tingkat pendapatan yang terkategori tinggi hanya dua persen. Hal ini mengindikasi bahwa kegiatan usahatani yang dilakukan selama ini menghasilkan pendapatan di bawah rata-rata, yang berarti upaya peningkatan pendapatan petani penting untuk ditingkatkan melalui program-program pemberdayaan petani. Karakteristik individu penerima manfaat program dapat dilihat pada Tabel 1.

Tabel 1.Jumlah dan persentase karakteristik individu penerima manfaat program pertanian metode SRI Organik, 2017

\begin{tabular}{llcr}
\hline Karakteristik Individu & Kategori & $\begin{array}{r}\text { Jumlah } \\
\text { (orang) }\end{array}$ & Persentase (\%) \\
\hline Umur (tahun) & Muda & 2 & 4.00 \\
$18-29$ & Dewasa & 30 & 53.00 \\
$30-49$ & Tua & 24 & 43.00 \\
$>49$ & & & \\
Tingkat Pendidikan (tahun) & Rendah & 39 & 70.00 \\
SD (1-6) & Sedang & 17 & 30.00 \\
SMP-SMA (7-12) & Tinggi & 0 & 0.00 \\
Perguruan Tinggi (>12) & & & \\
Jenis Kelamin & & 19 & 66.00 \\
Laki-laki & & 37 & 34.00 \\
Perempuan & Baru & 25 & 45.00 \\
Pengalaman Bertani (tahun) & Sedang & 29 & 52.00 \\
$<20$ & Lama & 2 & 3.00 \\
$20-40$ & & & \\
$>40$ & Rendah & 25 & 45.00 \\
Tingkat Pendapatan (Rp) & Sedang & 30 & 53.00 \\
$<500.000$ & Tinggi & 1 & 2.00 \\
$500.000-2.500 .000$ & & 56 & 100.00 \\
$>2.500 .000$ & & & \\
\hline Total & & &
\end{tabular}

\section{Komunikasi Partisipatif dalam Konteks Kewirausahaan Sosial}

Komunikasi partisipatif menurut Tufte dan Mefalopulos (2009) yaitu dengan mengacu pada empat prinsip yang saling mendukung satu sama lain, yaitu dialog, berpendapat, pembebasan pedagogi dan aksi-refleksi. Kegiatan penyuluhan program pertanian padi organik metode SRI dilakukan secara intensif oleh field facilitator (FF) Harfa melalui kegiatan sekolah lapang SRI berupa belajar di kelas dan praktik di lahan hingga panen. Intensitas komunikasi partisipatif yang terjadi dalam program pertanian padi organik metode SRI tersebut sangat tinggi. Artinya proses komunikasi partisipatif tersebut menekankan pada komunikasi dua arah, dimana tidak terdapat perbedaan antara sumber dan penerima dalam mencapai tujuan bersama. Intensitas komunikasi partisipatif yang tinggi tersebut terjadi karena antusias IPM yang didorong harapan tinggi dalam peningkatan mutu hidup melalui program pertanian. Selain itu peran serta dukungan local leader seperti aparatur desa, ketua kelompok tani dan gabungan kelompok tani, serta penyuluh pertanian lapang (PPL) Dinas Pertanian.

Tingkat kewirausahaan sosial mengacu pada Hulgard (2010) dengan empat indikator yang melekat pada individu maupun organisasi, yaitu menciptakan 
manfaat sosial, menjadi agen perubahan, melakukan inovasi sosial, dan melakukan aktivitas ekonomi. Program pertanian padi organik metode SRI telah memberikan manfaat bagi IPM, terutama peningkatan kapasitas dan pengetahuan masyarakat dalam berusahatani yang berkelanjutan. Penyuluhan program pertanian padi organik metode SRI yang dilakukan oleh Harfa dan mitra sudah dirasa cukup baik. Seiring berjalannya waktu melalui program ini pula sudah banyak perubahan dalam bertani. Perubahan yang terjadi di Desa Parigi diantaranya pemanfaatan bahan lokal seperti jerami, kotoran ternak, dan bahan lainnya sebagai sumber utama pupuk kompos, sehingga secara tidak langsung memberikan manfaat kepada lingkungan. Selain itu, dengan meningkatnya pengetahuan IPM terhadap pertanian organik metode SRI memberikan manfaat edukatif bagi petani lain. Saat ini, beberapa anggota Kelompok Barokah Tani sudah menjadi pelatih bagi kelompok tani mitra Harfa di dalam maupun luar Desa Parigi.

Agen-agen perubahan pertanian di Desa Parigi telah terbentuk melalui pendekatan stakeholder. Terbentuknya agen-agen perubahan di Desa Parigi terjadi karena harapan dan tekad bersama untuk memajukan daerahnya. Hal ini senada dengan yang disampaikan oleh Dees dalam Seelos dan Mair (2004). Wirausaha sosial memainkan aturan dari agen perubahan pada sektor sosial: (1) mengadopsi misi untuk menciptakan manfaat sosial, (2) mengenali dan mengejar dengan cepat peluang baru untuk mencapai misi (sosial), (3) melibatkan diri dalam sebuah proses inovasi, adaptasi, dan belajar berkelanjutan, (4) bergerak dengan keterbatasan sumber daya, (5) memperlihatkan rasa tanggung jawab yang tinggi.

Responden penerima manfaat telah melakukan inovasi sosial yang dipadukan dengan kearifan lokal. Sebagian besar IPM telah melakukan inovasi sosial (pertanian padi organik metode SRI) dengan memadukan dengan kearifan lokal yang ada di Desa Parig. Kearifan lokal dalam pertanian yaitu gotong royong atau biasa disebut dengan istilah liuran. Liuran dipadukan dengan inovasi sosial (pertanian padi organik metode SRI) yang telah diterapkan di Desa Parigi. Liuran adalah kegiatan gotong royong suatu kelompok masyarakat atau petani dalam melakukan pengolahan lahan pertanian. Pengolahan lahan dilakukan bergiliran di lahan masing-masing anggota yang tergabung dalam kelompok liuran.

Karakteristik Penerima Manfaat (IPM) menjalankan pertanian padi organik metode SRI berdasarkan keuntungan-keuntungan yang dirasakan. Hal ini dapat dilihat pada sebagian IPM yang telah menjalankan usahatani padi organik metode SRI dengan mengharapkan peningkatan pendapatan (berpikir rasional), namun kondisi yang tidak memungkinkan. Sebagian besar IPM berstatus petani buruh dan menggarap lahan pertanian dengan ukuran lahan kecil (0.1-0.25 ha), sehingga hasil panen padi yang didapat hanya dapat memenuhi kebutuhan sehari-hari keluarga (perilaku subsisten).

\section{Hubungan Karakteristik IPM Program dengan Persepsi Kemanfaatan Program Pertanian Padi Organik Metode SRI}

Berdasarkan analisis dengan menggunakan korelasi khi kuadrat menunjukkan bahwa tidak terdapat hubungan nyata antara karakteristik individu 
penerima manfaat (IPM) dengan persepsi kemanfaatan program. Hal ini menunjukkan bahwa karakteristik IPM pada program pertanian padi organik metode SRI di Desa Parigi tidak berhubungan maupun berpengaruh terhadap persepsi kemanfaatan program satu sama lain. Koefisien korelasi antara karakteristik IPM dengan persepsi kemanfaatan program dapat dilihat pada Tabel 2.

Tabel 2. Koefisien korelasi khi kuadrat $\left(\chi^{2}\right)$ karakteristik IPM dengan persepsi kemanfaatan program

\begin{tabular}{lc}
\hline \multicolumn{1}{c}{ Karakteristik Individu Penerima Manfaat } & Persepsi Kemanfaatan Program \\
\hline Umur & 0.840 \\
Tingkat Pendidikan & 0.175 \\
Jenis Kelamin & 0.411 \\
Pengalaman Bertani & 0.614 \\
Tingkat Pendapatan & 0.970 \\
\hline
\end{tabular}

Keterangan: berhubungan tidak nyata pada $p>0.05$

\section{Hubungan Intensitas Komunikasi Partisipatif dengan Persepsi Kemanfaatan Program}

Berdasarkan hasil analisis menggunakan korelasi rank Spearman, peubah intensitas komunikasi partisipatif memiliki hubungan sangat nyata pada $p<0.01$ dengan peubah persepsi kemanfaatan program. Hal ini mengindikasikan terdapat pengaruh positif dengan melakukan peningkatan intensitas komunikasi partisipatif terhadap persepsi kemanfaatan program pertanian padi organik metode SRI di Desa Parigi. Dengan demikian korelasi antara peubah intensitas komunikasi partisipatif dengan persepsi kemanfaatan program diterima. Koefisien korelasi intensitas komunikasi partisipatif dengan persepsi kemanfaatan program ditunjukkan pada Tabel 3.

Tabel 3. Koefisien korelasi rank Spearman $\left(r_{s}\right)$ intensitas komunikasi partisipatif dengan persepsi kemanfaatan program

\begin{tabular}{|c|c|c|}
\hline Douph & \multicolumn{2}{|c|}{ Persepsi Kemanfaatan Program } \\
\hline reundil & $r_{s}$ & Sig. (2-tailed) \\
\hline Intensitas & $0.373 * *$ & \\
\hline Komunikasi Partisipatif & & 0.005 \\
\hline
\end{tabular}

Ket: ${ }^{* *}$ Berhubungan sangat nyata pada $p<0,01$

Intensitas komunikasi partisipatif ditunjukkan berdasarkan indikator dialog, berpendapat, pembebasan pedagogi dan refleksi aksi, sedangkan persepsi kemanfaatan program ditunjukkan berdasarkan indikator keuntungan relatif, kompatibilitas, kompleksitas, eksperimental dan observatif. Berdasarkan hasil analisis dengan korelasi rank Spearman didapatkan indikator-indikator penelitian pada peubah intensitas komunikasi partisipatif memiliki hubungan nyata hingga sangat nyata pada $\mathrm{p}<0,01$ dengan peubah persepsi kemanfaatan program. Koefisien korelasi antara intensitas komunikasi partisipatif dengan persepsi kemanfaatan program disajikan pada Tabel 4. 
Tabel 4. Koefisien korelasi rank Spearman $\left(r_{s}\right)$ indikator intensitas komunikasi partisipatif dengan persepsi kemanfaatan program

\begin{tabular}{|c|c|c|c|c|c|}
\hline \multirow{2}{*}{$\begin{array}{l}\text { Intensitas } \\
\text { Komunikasi } \\
\text { Partisipatif }\end{array}$} & \multicolumn{5}{|c|}{ Persepsi Kemanfaatan Program } \\
\hline & $\begin{array}{l}\text { Keuntungan } \\
\text { Relatif }\end{array}$ & Kompatibilitas & Kompleksitas & Eksperimental & Observatif \\
\hline Dialog & $0.291 *$ & $0.316^{*}$ & 0.207 & 0.069 & 0.053 \\
\hline Berpendapat & $0.343^{* *}$ & 0.119 & 0.219 & 0.178 & 0.015 \\
\hline $\begin{array}{l}\text { Pembebasan } \\
\text { pedagogi }\end{array}$ & $0.294^{*}$ & -0.052 & 0.233 & $0.338^{*}$ & -0.063 \\
\hline Refleksi Aksi & $0.398^{* *}$ & 0.247 & $0.336^{*}$ & $0.297 *$ & -0.040 \\
\hline
\end{tabular}

Keterangan: *Berhubungan nyata pada $\mathrm{p}<0.05 ;{ }^{* *}$ Berhubungan sangat nyata pada $\mathrm{p}<0.01$

Hasil analisis koefisien korelasi antara indikator intensitas komunikasi partisipatif dengan persepsi kemanfaatan program yaitu intensitas dialogis berhubungan nyata pada $p<0.05$ dengan persepsi kemanfaatan program dari sisi keuntungan relatif dan kompatibilitas inovasi. Artinya semakin tinggi intensitas dialogis yang terjadi dalam program pertanian padi organik metode SRI, maka persepsi IPM terhadap keuntungan relatif dan kesesuaian inovasi terhadap nilainilai budaya akan semakin meningkat. Intensitas IPM berpendapat berhubungan sangat nyata pada $p<0.01$ dengan persepsi kemanfaatan program terhadap keuntungan relatif program. Artinya semakin tinggi intensitas IPM berpendapat dalam program pertanian padi organik metode SRI, maka persepsi IPM terhadap keuntungan relatif semakin meningkat. Pembebasan pedagogi berhubungan nyata pada $\mathrm{p}<0.05$ dengan persepsi keuntungan komparatif dan eksperimental. Artinya semakin tinggi pembebasan pedagogi dalam program pertanian padi organik metode SRI, maka persepsi IPM terhadap keuntungan relatif dan eksperimental semakin meningkat. Refleksi aksi berhubungan sangat nyata pada $p<0.01$ dengan persepsi kemanfaatan terhadap keuntungan relatif program. Artinya semakin tinggi IPM mengaplikasikan hasil pelatihan, maka persepsi IPM terhadap keuntungan relatif program semakin meningkat.

\section{Hubungan Intensitas Komunikasi Partisipatif dan Persepsi Kemanfaaatan Program dengan Kewirausahaan Sosial}

Komunikasi partispatif dalam konteks kewirausahaan sosial pada penelitian ini adalah suatu upaya komunikasi pembangunan yang memunculkan partisipasi kemandirian petani dalam menjalankan usahatani berkelanjutan yang berwawasan sosial, lingkungan dan budaya. Pada konteks kewirausahaan sosial, paling tidak akan ditemukan tiga istilah yang saling berkaitan, yaitu aktivitas kewirausahaan sosial (social enterpreneurship), wirausaha sosial atau orang yang melakukannya (social enterpreneur) dan institusi atau perusahaan sosial yang menaungi aktivitas kewirausahaan sosial (social enterprise) (Wibowo dan Nulhaqim 2015). Berdasarkan hasil penelitian didapat bahwa intensitas komunikasi partisipatif program pertanian padi organik metode SRI berhubungan sangat nyata pada $p<0,01$ dengan tingkat kewirausahaan sosial, sedangkan persepsi kemanfaatan program pertanian padi organik metode SRI berhubungan nyata pada $p<0,05$ dengan tingkat kewirausahaan sosial. Hasil uji korelasi rank Spearman intensitas komunikasi partisipatif dan persepsi 
kemanfaatan program dengan tingkat kewirausahaan sosial di Desa Parigi dijelaskan pada Tabel 5.

Tabel 5. Koefisien korelasi rank Spearman $\left(r_{s}\right)$ intensitas komunikasi partisipatif dan persepsi kemanfaatan program dengan kewirausahaan sosial

\begin{tabular}{|c|c|c|}
\hline \multirow{2}{*}{ Peubah } & \multicolumn{2}{|c|}{ Kewirausahaan Sosial } \\
\hline & $r_{s}$ & Sig. (2-tailed) \\
\hline Intensitas Komunikasi Partisipatif & $0.523^{* *}$ & 0.000 \\
\hline Persepsi Kemanfaatan Program & $0.329 *$ & 0.013 \\
\hline \multicolumn{3}{|l|}{$\begin{array}{l}\text { Ket: } \quad \text { *Berhubungan nyata pada } p<0.05 ; \\
\quad * * \text { Berhubungan sangat nyata pada } p<0.01\end{array}$} \\
\hline \multicolumn{3}{|c|}{$\begin{array}{l}\text { Indikator tingkat kewirausahaan sosial yang berhubungan tersebut } \\
\text { mencakup penilaian terhadap manfaat sosial, agen perubahan, inovasi sosial dan } \\
\text { kegiatan ekonomi. Hasil uji korelasi pada Tabel } 6 \text { menunjukkan hubungan } \\
\text { indikator intensitas komunikasi partisipatif dan persepsi kemanfaatan program } \\
\text { dengan indikator tingkat kewirausahaan sosial. }\end{array}$} \\
\hline
\end{tabular}

Tabel 6. Koefisien korelasi rank Spearman $\left(r_{s}\right)$ indikator intensitas komunikasi partisipatif dan persepsi kemanfaatan program dengan indikator kewirausahaan sosial, 2017

\begin{tabular}{lllll}
\hline \multicolumn{1}{c}{ Peubah } & \multicolumn{4}{c}{ Tingkat Kewirausahaan Sosial } \\
\hline \multicolumn{1}{c}{ Indikator } & $\begin{array}{c}\text { Manfaat } \\
\text { Sosial }\end{array}$ & $\begin{array}{c}\text { Agen } \\
\text { Perubahan }\end{array}$ & $\begin{array}{c}\text { Inovasi } \\
\text { Sosial }\end{array}$ & $\begin{array}{c}\text { Kegiatan } \\
\text { Ekonomi }\end{array}$ \\
\hline Intensitas Komunikasi Partisipatif & & & & \\
$\quad$ Dialog & $0.312^{*}$ & $0.460^{* *}$ & $0.561^{* *}$ & $0.385^{* *}$ \\
$\quad$ Berpendapat & $0.374^{* *}$ & $0.386^{* *}$ & $0.472^{* *}$ & $0.420^{* *}$ \\
$\quad$ Pembebasan Pedagogi & 0.198 & $0.307^{*}$ & $0.384^{* *}$ & $0.317^{*}$ \\
$\quad$ Refleksi Aksi & 0.239 & $0.427^{* *}$ & $0.517^{* *}$ & 0.229 \\
Persepsi Kemanfaatan Program & & & & \\
$\quad$ Keuntungan Relatif & 0.260 & $0.406^{* *}$ & $0.275^{*}$ & 0.099 \\
$\quad$ Kompatibilitas & 0.077 & 0.174 & 0.099 & 0.027 \\
$\quad$ Kompleksitas & $0.334^{*}$ & $0.440^{* *}$ & 0.262 & 0.107 \\
$\quad$ Eksperimental & 0.101 & 0.173 & 0.218 & 0.103 \\
Observatif & 0.178 & 0.093 & -0.031 & 0.197 \\
\hline
\end{tabular}

Keterangan: *Berhubungan nyata pada $\mathrm{p}<0,05 ;{ }^{* *}$ Berhubungan sangat nyata pada $\mathrm{p}<0,01$

Berdasarkan analisis dengan korelasi rank Spearman pada Tabel 6 menunjukkan bahwa sebagian besar indikator intensitas komunikasi partisipatif berhubungan nyata hingga sangat nyata dengan indikator tingkat kewirausahaan sosial. Indikator dialog dan berpendapat dalam intensitas komunikasi partisipatif memiliki hubungan nyata pada $\mathrm{p}<0.05$ (indikator dialog terhadap manfaat sosial) dan sangat nyata pada $\mathrm{p}<0.01$ (pada semua indikator). Artinya semakin meningkatnya intensitas dialog dan berpendapat individu penerima manfaat dalam program pertanian padi organik metode SRI, maka berimplikasi pada peningkatan tingkat kewirausahaan sosial. Indikator pembebasan pedagogi pada intensitas komunikasi partisipatif memiliki hubungan yang nyata pada agen perubahan dan aktivitas ekonomi (pada $p<0.05$ ) dan berhubungan sangat nyata 
pada inovasi sosial, namun tidak terdapat hubungan dengan manfaat sosial. Artinya pembebasan pedagogi sudah sesuai, sehingga berimplikasi pada peningkatan dalam menjadi agen perubahan, melakukan aktivitas ekonomi dan inovasi sosial. Indikator refleksi aksi diketahui memiliki hubungan sangat nyata pada $p<0.01$ terhadap agen perubahan dan inovasi sosial, namun tidak berhubungan dengan manfaat sosial dan aktivitas ekonomi. Artinya melalui peningkatan refleksi aksi individu penerima manfaat pada program pertanian padi organik metode SRI, maka berimplikasi pada peningkatan menjadi agen perubahan dan melakukan inovasi sosial.

Selanjutnya analisis korelasi rank Spearman pada Tabel 6 menunjukkan sebagian besar indikator persepsi kemanfaatan program tidak berhubungan nyata dengan tingkat kewirausahaan sosial. Indikator-indikator persepsi kemanfaatan program yang berhubungan nyata dengan tingkat kewirausahaan sosial yaitu keuntungan relatif dan kompleksitas. Keuntungan relatif yang dirasakan IPM dalam memutuskan pengadopsian inovasi pertanian padi organik metode SRI berhubungan sangat nyata pada $p<0.01$ dengan terbentuknya agen perubahan dan berhubungan nyata pada $p<0.05$ dengan melaksanakan inovasi sosial. Artinya semakin tinggi persepsi IPM terhadap keuntungan relatif inovasi tersebut, maka terbentuknya agen perubahan untuk melakukan inovasi sosial dalam kewirausahaan sosial akan semakin meningkat. Kompleksitas (kemudahan) inovasi pertanian padi organik metode SRI berhubungan nyata pada $p<0.05$ dengan menciptakan manfaat sosial dan berhubungan sangat nyata pada $p<0.01$ dengan terbentuknya agen perubahan. Artinya peningkatan persepsi kompleksitas, maka akan meningkatkan penciptaan manfaat sosial dan terbentuknya agen perubahan dalam pengembangan pertanian padi organik metode SRI.

\section{SIMPULAN DAN SARAN}

Karakteristik individu penerima manfaat (IPM) program pertanian padi organik metode SRI terdiri dari rataan umur yang berkategori dewasa hingga tua. Tingkat pendidikan formal IPM sebagian besar rendah (SD). Mayoritas IPM berjenis kelamin perempuan. Sebagian besar pengalaman bertani IPM berkategori baru hingga sedang. Rataan tingkat pendapatan IPM berkategori rendah hingga sedang.

Hasil uji korelasi khi kuadrat menerangkan bahwa karakteristik IPM tidak berhubungan nyata dengan persepsi kemanfaatan program, sehingga karakteristik IPM dalam semua kategori memiliki peluang yang sama dalam menjalankan usahatani padi organik metode SRI. Terdapat hubungan intensitas komunikasi partisipatif dengan persepsi kemanfaatan program, sehingga mengartikan pentingnya intensitas komunikasi partisipatif agar persepsi IPM terhadap kemanfaatan program dapat meningkat. Selain itu, terdapat hubungan persepsi kemanfaatan program dengan tingkat kewirausahaan sosial yang mengindikasikan pentingnya persepsi kemanfaatan program dalam pengembangan kewirausahaan sosial melalui program pertanian padi organik metode SRI. 
Komunikasi partisipatif yang intensif dalam pembangunan pertanian padi organik metode SRI telah memberikan dampak positif bagi pengembangan kewirausahaan sosial di Desa Parigi melalui pelatihan pada program pertanian padi organik metode SRI. Hal ini diperkuat dengan adanya hasil uji korelasi rank Spearman yang menjelaskan bahwa terdapat hubungan intensitas komunikasi partisipatif dengan tingkat kewirausahaan sosial.

Potensi peningkatan kewirausahaan sosial terutama pada aktivitas ekonomi (pemasaran produk pertanian padi organik) sangat memerlukan dukungan banyak pihak seperti pemerintah daerah maupun pusat, perusahaan swasta yang bergerak di bidang pertanian padi organik dan masyarakat secara umum melalui peningkatan kemitraan dengan pihak tersebut. Pengembangan pertanian padi organik metode SRI di Desa Parigi perlu pelatihan lebih lanjut ke arah pengembangan manajemen bisnis dan mengupayakan permodalan agar pengembangan usahatani terkelola dengan baik melalui kelompok-kelompok tani yang sudah terbentuk.

\section{DAFTAR PUSTAKA}

[BPS] Badan Pusat Statistik Kabupaten Pandeglang. 2015. Kabupaten Pandeglang dalam Angka. Banten (ID): BPS Kabupaten Pandeglang.

Creswell JW. 2010. Research Design, Pendekatan Kualitatif, Kuantitatif, dan Mixed. Yogyakarta (ID): Pustaka Belajar.

Hulgard L. 2010. Discourses of Social Entrepreneurship-Variation of The Same Theme? Working Paper. WP no. 10/01. Belgia (BE): EMES European Research Network.

[Kemensos] Kementerian Sosial. 2009. Undang-Undang Republik Indonesia Nomor 11 Tahun 2009 Tentang Kesejahteraan Sosial. Internet. [diacu pada 2016 November 142016]. Tersedia pada: http://sosialnews.com/ sosial/undang-undang-dan-peraturan-tentang-kesejahteraan-sosial-2.html.

Machmuddin N. 2016. Analisis Efisiensi Ekonomi Usahatani Padi Organik dan Konvensional. [tesis]. Bogor (ID): IPB.

Mardikanto T. 2010. Komunikasi Pemba-ngunan. Surakarta (ID): UNS Press.

Mayrowani H. 2012. Pengembangan pertanian organik di Indonesia. Forum Penelitian Agro Ekonomi. 30 (2): 91-108.

Muchtar K. 2016. Penerapan komunikasi partisipatif pada pembangunan di Indonesia. Jurnal makna. 1(1): 20-32.

Seelos C, Mair J. 2004. Social Entrepreneurship the contribution of individual entrepreneurs to sustainable development. Working Paper. WP No. 553. Anselmo Rubiralta Center for Globalization and strategy Center for Business in Society. University of Navara.

Sugarda JG, Charina A, Setiagustina L, Setiawan I. 2008. Kajian pengembangan usahatani padi organik SRI (System of Rice Intensification) berwawasan agribisnis dalam mendukung program ketahanan pangan secara berkelanjutan. Jurnal Agrikultura. 19(1): 15-25. 
Tufte T, Mefalopulos P. 2009. Participatory Communication: A Practical Guide. Washington (US): World Bank.

Wibowo H, Nulhakim SA. 2015. Kewirausahaan Sosial Merevolusi Pola Pikir Menginisiasi Mitra Pembangunan. Bandung (ID): Unpad Press. [Internet]. [Diunduh 20 Desember 2015]. Terdapat pada: http://pustaka.unpad.ac.id/wp-content /uploads/2015/03/6Kewirausahaan-Sosial.pdf. 